\title{
Returns to Education and Gender Differentials in Wages in Pakistan
}

\author{
Masood Sarwar Awan* and Zakir Hussain
}

\section{Abstract}

Education is one of the most important factors in human development. The data from two household surveys were used to estimate the returns to education and gender disparities in wages in Pakistan. The model, an extension of Becker and Mincer models, was used to quantify the returns to investment in education. The results revealed that income gaps attributable to education level were significant. Income gaps between educated and uneducated workers in first-time employment also tend to increase with experience. Women earn significantly less than their male counterparts. These differences may be interpreted as the maximum possible effect of discrimination against women. Women also earn less because they acquire less cumulative work experience than men, as a result of breaks in their work histories, owning to the demand of motherhood and domestic chores. Education quality was much lower for students from poor families; the majority of these poor attended public school and did not have access to better quality private schools. Such differences strengthened the influence of the distribution of education and the structure of returns on income concentration.

Key words: Earnings function, gender inequality, human capital.

\section{Introduction}

The return to investment in education is a sine qua non for human capital formation. Expenditure on education, whether by the state or household, is treated as an investment flow that builds human capital (Schultz 1961; Becker 1962). Human capital is a broad concept that identifies characteristics acquired by individuals in order to increase income. This commonly includes people's knowledge and skills through

\footnotetext{
* Assistant Professor, Department of Economics, University of Sargodha.

** Professor and Chairman, Department of Economics, University of Sargodha.
} 
education, and their strength and vitality deriving from their health and nutritional status. All these factors affect earnings and consumption because these factors improve mental and physical abilities of the people, raise their productivity and thus help the economy grow. Therefore, human capital is vital for the development of an economy.

Human Capital theory takes into account the growth of knowledge, skills and abilities of individuals and emphasizes the augmentation of the educated population and skilled manpower. Nevertheless human capital formation is a prerequisite for the development of physical capital and serves as a key to sustainable development. In the human capital model, an individual's earnings are the output of his own production function, where education and experience are treated as the factors of production.

Inequality in income results from the distribution of human capital across individuals in a non-degenerate way. Human capital formation is influenced by 'home-education', imparted by the parents, as well as formal public and private sector schooling. However, there is dualism in school education; the large majority is in the public school, and the children of the elite group receive education from convent type (private) schools. The literacy life expectancy (LLE) was 27 years and 13 for male and female respectively; the LLE for men was at least twice than for women (Lutz et al, 2004).

The Human Capital model in this study is an extension of Becker (1962) and Mincer (1974) models, used to quantify the returns to investment in education. Since education is the main source of human capital development, a large number of studies have estimated the returns to education for different countries [(Psacharopoulos, 1980, 1985, and 1994); (Psacharopoulos and $\mathrm{Chu} \mathrm{Ng,1992)].} \mathrm{These} \mathrm{studies} \mathrm{mostly} \mathrm{have} \mathrm{used}$ binary instead of continuous variables. There were only a few studies available in Pakistan that used the Mincerian Earnings Function approach to examine the returns to education [e.g. (Shabbir and Khan, 1991); (Shabbir, 1994); (Nasir and Nazli, 2000)]. The previous studies estimated the earnings function only for wage earners, whereas this study provides estimates for earnings functions of all employed groups (employers, self-employed, wage earners, unpaid family workers) by using the most recent data sets available in Pakistan. The Mincerian earnings function was based on the assumption of uniform rates of return for all schooling. 


\section{Data and Methodology}

We have used the Pakistan Integrated Household Survey (PIHS) 1998-99 and 2001-02 in this study. The sample size for the 1998-99 PIHS was 16,305 households, approximately one third of which was urban. A total of 1,150 PSUs were selected. The survey covered all the four provinces, including Azad Jammu and Kashmir, Northern Areas and FATA.

The sample size of the 1998-99 PIHS survey was large enough to obtain estimates for each province and region (urban/rural). A two-stage, stratified random sampling strategy was adopted for each of the surveys. At the first sampling stage, a number of Primary Sampling Units (PSUs) were selected from the different strata. The enumerators then compiled lists of all households residing in the selected PSUs. At the second sampling stage, these lists were used to select a sample of households from each PSU randomly. In all twelve households were selected in each urban PSU, and sixteen in each rural PSU.

\section{PIHS 2000-01}

A sample size of 16,400 households was taken to provide reliable estimates of key characteristics. The entire sample of households (SSUs) was drawn from 1150 Primary Sampling Units (PSUs) out of which 500 were urban and 650 were rural. In this survey 90 sample households were not covered due to non-response/closed/non-contact and non-cooperation from the respondents. 
Table 1.1: Profile of the 1998-99 and 2001-02 PIHS samples.

\begin{tabular}{|c|c|c|c|c|c|c|}
\hline \multirow[t]{2}{*}{ Province } & \multicolumn{3}{|c|}{ 1998-99 PIHS } & \multicolumn{3}{|c|}{ 2001-02 PIHS } \\
\hline & Urban & Rural & Overall & Urban & Rural & Overall \\
\hline \multicolumn{7}{|c|}{ PSU'S } \\
\hline Punjab & 220 & 238 & 458 & 220 & 238 & 458 \\
\hline Sindh & 128 & 136 & 264 & 128 & 136 & 264 \\
\hline NWFP & 72 & 116 & 188 & 72 & 116 & 188 \\
\hline Balochistan & 52 & 88 & 140 & 52 & 88 & 140 \\
\hline AJK & 16 & 28 & 44 & 16 & 28 & 44 \\
\hline Northern areas & 12 & 20 & 32 & 12 & 20 & 32 \\
\hline FATA & ------ & 24 & 24 & ------- & 16 & 16 \\
\hline Overall & 500 & 650 & 1150 & 500 & 642 & 1142 \\
\hline \multicolumn{7}{|c|}{ Households } \\
\hline Punjab & 2590 & 3791 & 6381 & 2599 & 3796 & 6395 \\
\hline Sindh & 1536 & 2176 & 3712 & 1534 & 2174 & 3708 \\
\hline NWFP & 859 & 1852 & 2711 & 857 & 1842 & 2699 \\
\hline Balochistan & 612 & 1404 & 2016 & 623 & 1406 & 2029 \\
\hline AJK & 192 & 448 & 640 & 192 & 443 & 635 \\
\hline Northern areas & 143 & 319 & 462 & 144 & 317 & 461 \\
\hline FATA & ------- & 383 & 383 & ------ & 255 & 255 \\
\hline Overall & 5932 & 10373 & 16305 & 5949 & 10233 & 16182 \\
\hline \multicolumn{7}{|c|}{ Individuals } \\
\hline Punjab & 16758 & 24619 & 41377 & 17143 & 24636 & 41779 \\
\hline Sindh & 10052 & 15099 & 25151 & 11048 & 17200 & 28248 \\
\hline NWFP & 6610 & 14923 & 21533 & 6504 & 14545 & 21049 \\
\hline Balochistan & 5045 & 10875 & 15920 & 5056 & 10487 & 15543 \\
\hline AJK & 1298 & 2939 & 4237 & 1361 & 3004 & 4365 \\
\hline Northern areas & 1188 & 2453 & 3641 & 1089 & 2482 & 3571 \\
\hline FATA & ------- & 3137 & 3137 & ------- & 2169 & 2169 \\
\hline Overall & 40951 & 74045 & 114996 & 42201 & 74523 & 116724 \\
\hline
\end{tabular}

Source: PIHS 1998-99 \& 2001-02 
In order to examine the effect of different years of education on earnings, this study used a six level breakdown. In Pakistan, primary education consisted of five years, middle school eight years, and matriculation as ten years of schooling respectively. The intermediate (12 years schooling) certificate is the gateway to professional degree programme of four to five years and general Bachelor's degree programme of two years. Those who choose general education can pursue the Master's degree in a university for two more years. Nearly it takes sixteen to seventeen years in total to complete education at the Master's level in Pakistan. After obtaining the Master's degree, a student can proceed to the M.Phil or the PhD degree (Nasir, 2002).

Most econometric analyses do not test if the underlying data permit pooling over time, and across gender, region and province. These analyses, therefore, violate the basic aggregation assumption underlying their analysis that the underlying disaggregated functions are similar. Pooling dissimilar disaggregated functions violates the econometric requirements necessary to obtain generalizable unbiased results from the data. These results also lead to the one size fits all type of policy prescriptions that more often than not fail because they are not based on a realistic representation of reality.

In view of the above, we conducted statistical tests for similarity of functions across time, regions, province, and gender. These tests confirmed that the functions were dissimilar in all the cases tested. It is therefore incorrect to run regressions at the aggregate level without taking these differences into account explicitly. Hence regressions were run separately by time and gender (Annexure-1).

\section{Results and Discussion}

\subsection{Earning Function of Gender:}

In this study, a comprehensive analysis of the Gender Earnings Function was obtained. The explanatory variables of the earnings function comprised of years of schooling (education), experience (age minus years of education, and minus school starting age), experience ${ }^{2}$, and a dummy variable for gender (male $=1$, zero otherwise). The data in hand amply demonstrates that mean value of male and female wage rates were statistically different from each other $(\mathrm{p}>0.05)$.

The regression results are presented in Table-1.2, 1.3 and 1.4 for the overall sample, males and females respectively for the year 1998 and 2001. All coefficients had the expected sign, significant $(p>0.05)$ and 
consistent with economic theory. The coefficient on years of education showed that a 10.5 percent increase in earnings resulted from one extra year of school in year 1998-99 and 9.3 percent increase in earnings in the year 2000-2001. The coefficient on Experience was positive as expected; however the parameter of $(\operatorname{Exp})^{2}$ was negative, implying concavity of the earnings function.

Table 1.2: Regression results relating the earnings function with selected variables, Pakistan

(Overall sample)

\begin{tabular}{lcccc}
\hline \multirow{2}{*}{ Variable } & \multicolumn{2}{c}{ 1998-99 } & \multicolumn{2}{c}{ 2001-02 } \\
\cline { 2 - 5 } & Coefficient & t-value & Coefficient & t-value \\
\hline Constant & $4.713^{* * *}$ & 188.915 & $5.320^{* * *}$ & 186.681 \\
Experience & $0.065^{* * *}$ & 54.173 & $0.069^{* * *}$ & 50.197 \\
(Experience) $^{2}$ & $-0.001^{* * *}$ & -35.572 & $-0.001^{* * *}$ & -35.227 \\
Education & $0.105^{* * *}$ & 75.265 & $0.093^{* * *}$ & 60.374 \\
Male & $1.699^{* * *}$ & 104.094 & $1.363^{* * *}$ & 72.966 \\
Adj $\mathrm{R}^{2}$ & \multicolumn{2}{c}{0.491} & \multicolumn{2}{c}{0.363} \\
F-statistics & \multicolumn{2}{c}{5312.993} & 2994.104 \\
\hline
\end{tabular}

*** Significantly different from zero at the 1 percent probability leve1

Table-1.3: Regression results relating the earnings function with selected variables, Pakistan

(Male)

\begin{tabular}{lcccc}
\hline Variable & \multicolumn{2}{c}{ 1998-99 } & \multicolumn{2}{c}{ 2001-02 } \\
\cline { 2 - 5 } & Coefficient & t-value & Coefficient & t-value \\
\hline Constant & $6.400^{* * *}$ & 294.558 & $6.646^{* * *}$ & 260.237 \\
Experience & $0.069^{* * *}$ & 59.064 & $0.073^{* * *}$ & 52.515 \\
(Experience) $^{2}$ & $-0.001^{* * *}$ & -39.461 & $-0.001 * * *$ & -37.225 \\
Education & $0.093^{* * *}$ & 68.426 & $0.087^{* * *}$ & 57.139 \\
Adj R & \multicolumn{2}{c}{0.272} & \multicolumn{2}{c}{0.211} \\
F- statistics & \multicolumn{2}{c}{2394.012} & \multicolumn{2}{c}{1641.805} \\
\hline
\end{tabular}

*** Significantly different from zero at the 1 percent probability level 
Table 1.4: Regression results relating the earnings function with selected variables, Pakistan

(Female)

\begin{tabular}{lcccc}
\hline \multirow{2}{*}{ Variable } & \multicolumn{2}{c}{ 1998-99 } & \multicolumn{2}{c}{ 2001-02 } \\
\cline { 2 - 5 } & Coefficient & t-value & Coefficient & t-value \\
\hline Constant & $4.616^{* * *}$ & 55.179 & $5.451^{* * *}$ & 64.423 \\
Experience & $0.065^{* * *}$ & 13.182 & $0.063^{* * *}$ & 12.073 \\
${\text { (Experience })^{2}}^{-0.001^{* * *}}$ & -9.810 & $-0.001^{* * *}$ & -9.740 \\
Education & $0.181^{* * *}$ & 33.569 & $0.132^{* * *}$ & 25.397 \\
Adj R & \multicolumn{2}{c}{0.292} & \multicolumn{2}{c}{0.201} \\
F-statistics & \multicolumn{2}{c}{390.362} & \multicolumn{2}{c}{219.622} \\
\hline
\end{tabular}

**** Significantly different from zero at the 1 percent probability leve1

Among other results, a positive coefficient on the gender dummy (male) in the overall sample was indicative of a gender gap in labor market earnings. Females earned significantly less relative to their male counterparts. But the separate analysis for males and females showed that females enjoyed a higher return (18.1 percent and 13.2 percent) to education. These results are in line with the results of Altas and Bourguignon (2004) in case of Indonesia as well as that of Fields and Soares (2004) for Malaysia and Asadullah (2005) for Bangladesh. The coefficient on experience showed a substantial increase in wages with each additional year spent in the labor market for both male and female workers. The results for the year 1998 showed that five years of experience earned 35 percent higher wages for male workers and 32 percent higher wages for female workers as compared to their counterparts with no experience.

Similar results were obtained for the year 2001 where five years of experience earned 37.9 percent higher wages for male workers and 32.5 percent higher wages for female workers compared to male and female counterparts with no experience respectively. These results were consistent with prior studies in Pakistan [(Khan and Irfan, 1985); (Ashraf and Ashraf, 1993); (Nasir, 1999); and (Shabbir, 1991)]. 


\subsection{Earnings Function with Various Levels of Education by Gender}

Many studies have indicated substantial differences in earnings across schooling levels in different countries. Van der Gaag and Vijverberg (1989) noted that an increase of one year in elementary, high, and university education showed an increase of 12 percent, 20 percent, and 22 percent in earnings respectively. Nasir and Hina (2000) showed that an increase of one year in education at middle school level increased earnings by 9.8 percent for male workers and 2.9 percent for female workers.

Table 1.5: Regression Results Relating Earnings Function to Selected Variables at Various Levels of Education

(overall sample)

\begin{tabular}{lcccc}
\hline \multirow{2}{*}{ Variable } & \multicolumn{2}{c}{ 1998-99 } & \multicolumn{2}{c}{ 2001-02 } \\
\cline { 2 - 5 } Constant & Coefficient & t-value & Coefficient & t-value \\
Experience & $4.987^{* * *}$ & 183.933 & $5.537^{* * *}$ & 183.338 \\
${\text { (Experience })^{2}}$ & $0.059^{* * *}$ & 48.805 & $0.065^{* * *}$ & 47.034 \\
Urban & $-0.001^{* * *}$ & -33.148 & $-0.001^{* * *}$ & -34.464 \\
Punjab & $0.032^{* *}$ & 2.462 & -0.161 & -11.238 \\
NWFP & $-0.066^{* * *}$ & -4.698 & 0.015 & 1.021 \\
Balochistan & $-0.204^{* * *}$ & -9.660 & $0.097^{* * *}$ & 4.052 \\
Male & $0.183^{* * *}$ & 6.431 & -0.061 & -1.733 \\
Middle & $1.783^{* * *}$ & 107.585 & $1.436^{* * *}$ & 76.246 \\
Matric & $0.506^{* * *}$ & 24.892 & $0.442^{* * *}$ & 20.176 \\
Inter & $0.759^{* * *}$ & 39.928 & $0.727^{* * *}$ & 34.459 \\
BA & $1.035^{* * *}$ & 35.188 & $1.006^{* * *}$ & 31.200 \\
Prof & $1.337^{* * *}$ & 40.727 & $1.264^{* * *}$ & 35.291 \\
Adj R & $1.758^{* * *}$ & 43.232 & $1.653^{* * *}$ & 40.152 \\
F-statistics & \multicolumn{2}{c}{0.479} & \multicolumn{2}{c}{0.359} \\
\hline
\end{tabular}

*** Significantly different from zero at the 1 percent probability leve1

** Significantly different from zero at the 5 percent probability leve1 
Table-1.6: Regression Results Relating Earnings Function to Selected Variables at Various Levels of Education

(Male)

\begin{tabular}{lcccc}
\hline \multirow{1}{*}{ Variable } & \multicolumn{2}{c}{ 1998-99 } & \multicolumn{2}{c}{ 2001-02 } \\
\cline { 2 - 5 } Constant & Coefficient & t-value & Coefficient & t-value \\
\hline Exp & $6.729^{* * *}$ & 290.227 & $6.936^{* * * *}$ & 257.273 \\
$(\text { Exp })^{2}$ & $0.065^{* * *}$ & 54.986 & $0.069^{* * * *}$ & 49.651 \\
Urban & $-0.001^{* * *}$ & -38.074 & $-0.001^{* * *}$ & -36.586 \\
Punjab & $-0.034^{* *}$ & -2.645 & -0.204 & -13.900 \\
NWFP & $-0.075^{* * *}$ & -5.441 & -0.004 & -0.247 \\
Balochistan & $-0.236^{* * *}$ & -11.575 & $0.055^{* *}$ & 2.297 \\
Middle & $0.181^{* * *}$ & 6.633 & $-0.113^{* * *}$ & -3.235 \\
Matric & $0.487^{* * *}$ & 25.488 & $0.429^{* * *}$ & 19.880 \\
Inter & $0.705^{* * *}$ & 38.883 & $0.713^{* * * *}$ & 33.895 \\
BA & $0.925^{* * *}$ & 32.304 & $0.950^{* * * *}$ & 29.058 \\
Prof & $1.210^{* * *}$ & 37.853 & $1.146^{* * * *}$ & 30.829 \\
Adj R & $1.560^{* * *}$ & 38.849 & $1.500^{* * * *}$ & 35.162 \\
F-statistics & \multicolumn{2}{c}{0.259} & \multicolumn{2}{c}{438.885} \\
\hline
\end{tabular}

*** Significantly different from zero at the 1 percent probability level

** Significantly different from zero at the 5 percent probability level 
Table-1.7: Regression Results Relating Earnings Function to Selected Variables at Various Levels of Education

(Female)

\begin{tabular}{|c|c|c|c|c|}
\hline \multirow[t]{2}{*}{ Variable } & \multicolumn{2}{|c|}{$1998-99$} & \multicolumn{2}{|c|}{$2001-02$} \\
\hline & Coefficient & t-value & Coefficient & t-value \\
\hline Constant & $5.046^{* * *}$ & 56.189 & $5.675^{* * *}$ & 63.359 \\
\hline Exp & $0.043 * * *$ & 9.119 & $0.049 * * *$ & 9.609 \\
\hline$(\operatorname{Exp})^{2}$ & $0.000^{* * *}$ & -6.743 & $-0.001^{* * *}$ & -8.071 \\
\hline Punjab & 0.006 & 0.120 & $0.127^{* *}$ & 2.645 \\
\hline NWFP & -0.061 & -0.703 & $0.382^{* * *}$ & 3.678 \\
\hline Balochistan & 0.006 & 0.044 & $0.372^{* *}$ & 2.077 \\
\hline Middle & $0.886^{* * *}$ & 7.086 & $0.574^{* * *}$ & 5.212 \\
\hline Matric & $1.331^{* * *}$ & 15.121 & $0.890^{* *}$ & 9.799 \\
\hline Inter & $1.768^{* * *}$ & 15.632 & $1.396^{* * *}$ & 11.857 \\
\hline $\mathrm{BA}$ & $2.215^{* * *}$ & 17.526 & $1.736^{* * *}$ & 15.502 \\
\hline Prof & $2.713^{* * *}$ & 18.859 & $2.414^{* * * *}$ & 18.685 \\
\hline Urban & $0.366^{* * *}$ & 7.548 & $0.049^{* * *}$ & 1.011 \\
\hline Adj $R^{2}$ & \multicolumn{2}{|c|}{0.282} & \multicolumn{2}{|c|}{0.215} \\
\hline F-Statistics & \multicolumn{2}{|c|}{102.424} & \multicolumn{2}{|c|}{65.925} \\
\hline
\end{tabular}

*** Significantly different from zero at the 1 probability level

** Significantly different from zero at the 5 probability level

The results were obtained in Table-1.5, 1.6 and 1.7 for the overall sample, male and female sub-samples respectively for the years 1998 and 2001. ${ }^{1}$ The results revealed that returns to each year of education for male workers at the Matric level were 1.4 times, 1.9 times for inter, 2.5 times for BA, and 3.2 times higher for professionals as compared to middle school. Similarly for female workers the results at matric level were 1.5 times, 2 times for inter, 2.5 times for $\mathrm{BA}$ and 3.1 times higher for professionals as compared to the worker with middle class qualification. These results were

1 The excluded categories for the dummy variables are: Sindh (for the provincial dummies) and primary schooling (for the level of education). 
similar to several the previous studies [Hamadani (1975), Haque (1977) Khan \& Irfan (1985), Shabbir (1991)], but these results were relatively lower than those of Nasir and Hina (2000). The authors showed that returns to each year of education for male workers at matric level are three times, six times for degree education and approximately seven times higher for professional education than those of middle school years. Likewise for female workers the results were four times higher for matric, eight times higher for inter, thirteen times higher for $\mathrm{BA}$ and twenty times higher for professional degree holders as compared to the return for middle class qualification. The difference was perhaps due to the dependent variable used (only wage earners). In 2001, we estimated that returns to each year of education for male workers at the Matric level are 1.66 times, 2.2 times for inter, 2.67 times for BA and 3.5 times higher for professional as compared to the returns of workers with middle class schooling. The analysis showed that those who have professional degrees received the highest returns followed by BA holders. These results were again in line with previous studies in Pakistan. An interesting result from the provincial dummies is that the coefficient on Punjab, a prosperous province, is negative relative to the excluded province, Sindh. This may perhaps be due to higher wages in the suburbs of Karachi, the commercial capital. In addition, Sindh possibly started at a very low level of earnings.

\subsection{Earnings Function with Quality of Education}

In recent years, the cognitive skills of students have been widely debated by education experts. Students with higher cognitive skills performed better in their level of attainment in education. This in turn corresponded with a higher payoff in the labor market; there is little doubt that workers of higher cognitive skill have higher earnings, even among those with equal levels of education (Bossiere, Knight and Sabot, 1985).

Proponents of both education-as-screening device and human capital formation through education tend to agree that people with higher ability are likely to be more productive. The advocates of the screening point of view cite substantial literature suggesting there was almost no demonstrated relationship between schooling expenditure and student performance on tests of cognitive skill. (Hanushek, 1986). The advocates of the human capital view however found support in recent studies showing that, other things equal, students in states with higher teacher/student ratios and better-paid teachers obtained higher earnings (Card and Krueger, 1992). In the economics literature, normally private schooling is considered a proxy for the quality of education. Thus private school was used in this study as a dummy variable to capture the effect of 
education quality, along with other variables in the model discussed above. The results were shown in Tables 1.8, 1.9 and 1.10.

Table-1.8: Regression Results Relating Earnings Function to Selected Variables and Education Quality

(overall sample)

\begin{tabular}{|c|c|c|c|c|}
\hline \multirow[t]{2}{*}{ Variable } & \multicolumn{2}{|c|}{ 1998-99 } & \multicolumn{2}{|c|}{$2001-02$} \\
\hline & Coefficient & t-value & Coefficient & t-value \\
\hline Constant & $4.984^{* * *}$ & 183.842 & $5.531 * * *$ & 182.961 \\
\hline Exp & $0.059 * * *$ & 48.901 & $0.065^{* * * *}$ & 47.174 \\
\hline$(\operatorname{Exp})^{2}$ & $-0.001 * * *$ & -33.211 & $-0.001 * * *$ & -34.581 \\
\hline Urban & $0.029 * *$ & 2.181 & $-0.166^{* * *}$ & -11.544 \\
\hline Punjab & $-0.066^{* * * *}$ & -4.694 & 0.017 & 1.122 \\
\hline NWFP & $-0.203 * * *$ & -9.613 & $0.100 * * *$ & 4.176 \\
\hline Balochistan & $0.185^{* * *}$ & 6.501 & -0.059 & -1.662 \\
\hline Male & $1.784 * * *$ & 107.660 & $1.437 * * *$ & 76.306 \\
\hline Middle & $0.504 * * *$ & 24.792 & $0.439 * * *$ & 20.057 \\
\hline Matric & $0.755^{* * * *}$ & 39.710 & $0.725^{* * * *}$ & 34.396 \\
\hline Inter & $1.034 * * *$ & 35.181 & $1.005^{* * *}$ & 31.170 \\
\hline $\mathrm{BA}$ & $1.332^{* * *}$ & 40.572 & $1.257^{* * *}$ & 35.074 \\
\hline Prof & $1.748 * * *$ & 42.944 & $1.642 * * *$ & 39.805 \\
\hline Private & $0.246 * * *$ & 4.594 & $0.211^{* * *}$ & 3.964 \\
\hline Adj $R^{2}$ & \multicolumn{2}{|c|}{0.479} & \multicolumn{2}{|c|}{0.359} \\
\hline F-Statistics & \multicolumn{2}{|c|}{1563.079} & \multicolumn{2}{|c|}{908.517} \\
\hline
\end{tabular}

Significantly different from zero at the 1 percent probability leve1

**Significantly different from zero at the 5 percent probability level 
Table-1.9: Regression Results Relating Earnings Function to Selected Variables and Education Quality

(Male)

\begin{tabular}{lllll}
\hline \multirow{2}{*}{ Variable } & \multicolumn{2}{c}{ 1998-99 } & \multicolumn{2}{c}{ 2001-02 } \\
\cline { 2 - 5 } Constant & Coefficient & t-value & Coefficient & t-value \\
Exp & $6.726^{* * * *}$ & 290.186 & $6.931^{* * *}$ & 256.771 \\
$(\text { Exp })^{2}$ & $0.065^{* * *}$ & 55.096 & $0.070^{* * *}$ & 49.764 \\
Urban & $-0.001^{* * *}$ & -38.142 & $-0.001^{* * *}$ & -36.683 \\
Punjab & $-0.038^{* * *}$ & -2.945 & $-0.209^{* * * *}$ & -14.162 \\
NWFP & $-0.074^{* * *}$ & -5.433 & -0.003 & -0.174 \\
Balochistan & $-0.234^{* * *}$ & -11.525 & $0.058^{* *}$ & 2.400 \\
Middle & $0.183^{* * *}$ & 6.717 & $-0.111^{* * *}$ & -3.179 \\
Matric & $0.485^{* * *}$ & 25.402 & $0.428^{* * *}$ & 19.827 \\
Inter & $0.702^{* * *}$ & 38.670 & $0.712^{* * *}$ & 33.888 \\
BA & $0.925^{* * *}$ & 32.324 & $0.949^{* * *}$ & 29.053 \\
Prof & $1.205^{* * *}$ & 37.710 & $1.141^{* * *}$ & 30.646 \\
Private & $1.550^{* * *}$ & 38.576 & $1.491^{* * *}$ & 34.911 \\
Adj R & $0.270^{* * *}$ & 5.116 & $0.187^{* * *}$ & 3.381 \\
F-Statistics & & 0.260 & & 0.208 \\
\hline
\end{tabular}

*** Significantly different from zero at the 1 percent probability level

**Significantly different from zero at the 5 percent probability level 
Table-1.10: Regression Results Relating Earnings Function to Selected Variables and Education Quality

(Female)

\begin{tabular}{|c|c|c|c|c|}
\hline \multirow[t]{2}{*}{ Variable } & \multicolumn{2}{|c|}{ 1998-99 } & \multicolumn{2}{|c|}{ 2001-02 } \\
\hline & Coefficient & t-value & Coefficient & t-value \\
\hline Constant & $5.047 * * *$ & 56.192 & $5.673 * * *$ & 63.340 \\
\hline Exp & $0.043 * * *$ & 9.106 & $0.049 * * *$ & 9.606 \\
\hline$(\operatorname{Exp})^{2}$ & $0.000 * * *$ & -6.733 & $-0.001 * * *$ & -8.068 \\
\hline Urban & $0.369 * * *$ & 7.585 & 0.049 & 0.994 \\
\hline Punjab & 0.007 & 0.127 & $0.130 * * *$ & 2.704 \\
\hline NWFP & -0.062 & -0.715 & $0.387 * * *$ & 3.721 \\
\hline Balochistan & 0.005 & 0.037 & $0.378 * *$ & 2.119 \\
\hline Middle & $0.893 * * *$ & 7.123 & $0.550 * * *$ & 4.948 \\
\hline Matric & $1.335^{* * *}$ & 15.143 & $0.874 * * *$ & 9.554 \\
\hline Inter & $1.771 * * *$ & 15.652 & $1.386^{* * * *}$ & 11.755 \\
\hline $\mathrm{BA}$ & $2.221 * * *$ & 17.546 & $1.724 * * *$ & 15.355 \\
\hline Prof & $2.722 * * *$ & 18.867 & $2.390 * * *$ & 18.342 \\
\hline Private & 0.160 & 4.849 & 0.228 & 4.408 \\
\hline $\operatorname{Adj} R^{2}$ & \multicolumn{2}{|c|}{0.282} & \multicolumn{2}{|c|}{0.215} \\
\hline F-Statistics & \multicolumn{2}{|c|}{98.939} & \multicolumn{2}{|c|}{60.619} \\
\hline
\end{tabular}

**** Significantly different from zero at the 1 percent probability leve1

**Significantly different from zero at the 5 percent probability level

Results showed that male workers received substantial gains when receiving education from private schools in the years 1998 and 2001 respectively. In 1998, male students having education from private schools earned 27 percent higher income as compared to their peers who received a public school education, whereas in the year 2001 male students having education from private schools earned 18.7 percent higher income as compared to their peers who received public school education. Correspondingly, female workers who have private school education earned 16 percent more income than their female counterpart having public school 
education in 1998-99 and 22.8 percent more income in year 2001-02. These results showed that the quality of education in the private sector was better, which in turn increased the productivity of workers and helped increased the earnings of workers. We can also see that returns have fallen for men over the period $1998 / 99$ to $2001 / 02$, while the reverse was true for women. A possible explanation is that the public sector educational system is geared toward men, causing women to shift toward the private system. At the same time, graduates from the private school sector are preferred in the job market.

This study has analyzed different dimensions of labor income inequality and discussed education's central role in explaining these differences. Overall, the analysis has showed that female workers were receiving less compensation as compared to their male counterparts. Experience has also appeared as major contributor towards wage differentials and contributed to substantial increases in wages with each additional year of work experience. However, returns to experience were greater for men than women. Estimates showed that each year of schooling augments the earnings of an individual by one to three percent.

The number of years of education is only an approximate indicator of a person's educational level. An insufficient quality education yields a lower return and lower income during an individual's working life. If the education quality distribution is skewed against children from low income sectors of the population, it will constitute an additional conduit for labor income concentration, and ultimately for the replication of inequality. Poor education quality severely affects the income generation potential of persons from the lower-income brackets. Higher-income families have greater purchasing power, allowing them to afford a better education for their children. The earnings function with quality of education demonstrated that persons who get their education from good private institutions receive better compensation as compared with their counterparts with a public school background. As the analysis proved that better schooling can enhance the kind of skills that pay off in the labor market, so increased investment in the quality of the nation's schools could be instrumental in raising their earning potential and defusing the public-private disparity in school quality.

\section{Conclusions and Recommendations}

In summary, income gaps attributable to education level were significant. This implies that income inequality arose from the education distribution pattern, as well as from the way the labor market 
compensated education in Pakistan. Income gaps between educated and uneducated workers in first-time employment also tend to increase with experience. This occurs at different rates in individual with different levels of education.

Women earn significantly less than their male counterparts. These differences may be interpreted as the maximum possible effect of discrimination against women. The labor market does not provide equal pay for different types of employment. To the extent that more women tend to work in low-paying occupations, this was reflected in lower wages for women. Women earn less also because they acquire less cumulative work experience than men, as a result of breaks in their work histories owning to the demand of motherhood and housework traditionally assigned to them. There is a need to promote female education and bring women into the formal economic sector.

Education quality was much lower for students from poor families, as the majority of these poor attended public school and do not have access to better quality private schools. The poor may also be receiving a poorer "home education." So there were major quality differences in the education received by the poor and non-poor. These differences strengthened the influence of the distribution of education and the structure of returns on income concentration. 


\section{References}

Altas and Bourguignon, 2004, "The Evolution of Income Distribution during Indonesia's Fast Growth, 1980-96: The microeconomics of income distribution dynamics: Oxford University Press.

Asadullah, 2005, "Returns to education in Bangladesh" QEH working paper series-QEHWPS 130.

Ashraf, J. and Ashraf, B., 1993, "Estimating the Gender Wage Gap in Rawalpindi City”. Journal of Development Studies. Vo1. 24, No. 2.

Becker, Gary S., 1962, "Investment in Human Capital: A Theoretical Analysis”. Journal of Political Economy. Vol. 70, Supplement.

Booissiere, M., Knight, J. B. and Sabot, R. H., 1985, "Earning, Schooling, Ability and Cognitive Skills" American Economic Review. Vol 75, 1016-30.

Card, David and Alan B. Krueger, 1992, "Does School Quality Matter? Returns to Education and the Characteristics of Public Schools in the United States.” Journal of Political Economy, Vo1. 100, No. 1.

Field and Soares, 2004, The Microeconomics of changing income distribution in Malaysia The microeconomics of income distribution dynamics: Oxford University Press.

Gujrati, Damodar, N., 2005, Basic Econometrics. (4 ${ }^{\text {th }}$ edition). New York: MacGraw-Hill, Inc.

Hamdani, Khalil, 1977, "Education and the Income Differentials: An Estimation of Rawalpindi City”. The Pakistan Development Review. Vol XVI No. 2.

Hanushek, E. A., 1986, "The Economics of Schooling: Production and Efficiency in Public Schools.” Journal of Economic Literature 24(3): 1141-78.

Haque, Nadeemu1, 1977, "An Economic Analysis of Personal Earnings in Rawalpindi City”. The Pakistan Development Review. 16:4. 
Khan, S. R. and Irfan, M., 1985, "Rate of Returns to Education and Determinants of Earnings in Pakistan". The Pakistan Development Review. 34:3-4.

Lutz Wolfgang, Warren C. Sanderson, Sergei. Scherbov, 2004, The End of World Population Growth in the 21st Century: New Challenges for Human Capital.

Malik, S. J., 1996, "Determinants of rural poverty in Pakistan: a micro study", Pakistan Development Review, vol. 35, No. 2, summer edition, pp. 171-87.

Mincer, Jacob, 1974, Schooling, Experience and Earnings: New York: National Bureau of Economic Research.

Nasir, and Nazli, 2000, "Education and Earning in Pakistan" Pakistan Development Review, 43:1.

Nasir, Z. M., 1999, "Do Private Schools Make Workers More Productive". Pakistan Institute of Development Economics. Mimeo.

Nasir, Z. M., 2002, "Returns to Human Capital in Pakistan" Pakistan Development Review. 41:1 pp. 1-28.

Pasacharapoulos, G and Ying Chu Ng., 1992, "Earning and Educations in Latin America”. World Bank Working Paper Series No. 1056, World Bank. Washington, D.C.

Pasacharapoulos, G., 1980, "Returns to Education: An Updated International Comparison”. In T. King (ed.) Education and Income World Bank Staff Working Paper No. 402. Washington, D.C.

Pasacharapoulos, G., 1985, "Returns to Education: A Further International Update and Implications". The Journal of Human Resources, Vol. 20: 584-604.

Pasacharapoulos, G., 1994, "Returns to Investment in Education: A Global Update”. World Development. 22(9).

Schultz, T. W. "Investment in Human Capital." American Economic Review, 60 (1961): 1-15. 
Shabbir, T. and A. H. Khan, 1991, "Mincerian Earning Functions for Pakistan: A Regional Analysis”. Pakistan Economic and Social Review. Vol. XXIX, No. 2.

Shabbir, Tayyab, 1994, "Mincerian Earning Functions for Pakistan". The Pakistan Development Review. Vo1. 33, No. 1.

Stiglitz, Joseph E., 1969, "Distribution of income and wealth among individuals," Econometrica, 37(3), p. 382-397.

Van der Gaag, Jacques and Wim Vijverberg, 1989, "Wage Determinants in Côte d'Ivorie: Experience, Credentials and Human Capital." Economic Development and Cultural Change, 37:2. 


\section{Annexure-1}

\section{Time Dummy}

First, we run a simple Mincerian earning function consisting of the year dummy that is equal to one when the value is of year 2001 and zero otherwise. Test results show that both the intercept and slope dummy coefficients are highly significant and this shows that pooling of data sets of 1998 and 2001 is not recommended.

\begin{tabular}{cllcc}
\hline \multicolumn{1}{c}{ Intercept (t-value) } & \multicolumn{2}{c}{ Slope (t-value) } & Intercept and slope \\
\hline Yrdm (Year Dummy) & 35.738 & Educate & 92.278 & F-value $=2658.357$ \\
& Exp & 57.270 & \\
& $($ Exp) & -42.195 & \\
\hline
\end{tabular}

Due to this reason we have estimated separate regressions for different years.

We repeat this procedure for the gender dummies and results also show that the coefficient of the gender dummy (male) is highly significant which suggests that we should run separate regressions for males and females. Results of this test are given in the following table.

\section{Gender Dummy}

\begin{tabular}{llllllll}
\hline & \multicolumn{2}{c}{1998} & & & \multicolumn{2}{c}{2001} & \\
\hline Intercept & \multicolumn{2}{c}{ Slope } & \multicolumn{2}{c}{$\begin{array}{l}\text { Intercept } \\
\text { and slope }\end{array}$} & Intercept & Slope & $\begin{array}{l}\text { Intercept } \\
\text { and slope }\end{array}$ \\
\hline 104.094 & Exp & 54.173 & F-Value & 42.156 & Exp & 37.159 & F-Value \\
& $(\text { Exp) })^{2}$ & -35.572 & 5312.993 & & $(\text { Exp })^{2}$ & -34.096 & 1377.130 \\
& Educate & 75.265 & & & Educate & 43.933 & \\
\hline
\end{tabular}

